\title{
RETROSPECTIVE STUDY OF CANINE EPITHELIAL AND MELANOCYTIC TUMORS
}

\author{
ALEKSIĆ-KOVAČEVIĆ SANJA, KUKOLJ V, MARINKOVIĆ D and KNEŽEVIĆ MILIJANA
}

Faculty of Veterinary Medicine, Belgrade

(Received 21. March 2005)

Out of the total number of canine tumors examined at the Department of pathology based on biopsy and section materials over the last five years, skin tumors and mammary gland tumors were proved to be the two largest groups diagnosed in $33.4 \%$ and $36 \%$ of cases, respectively. Cutaneous tumors were diagnosed in 211 cases, i.e., in $123(58.3 \%)$ male dogs and 88 (41.7\%) bitches, of different breeds, on average 7 years old. Among the total number of 211 skin tumors, 32 types of cutaneous neoplasms were diagnosed, with epithelial and melanocytic tumors being the most predominant, followed by hematopoietic tumors and mesenchymal tumors of the skin and soft tissues. In our bioptic and section materials, epithelial and melanocytic skin tumors were the most frequent -123 cases (58.75\%) with four subgroups within the group: tumors with adnexal differentiation - 66 cases (53.23\% of all epithelial and melanocytic skin tumors), epidermal tumors - 25 cases $(20.16 \%$ of all epithelial and melanocytic skin tumors), tumors without squamous or adnexal differentiation - 16 cases (12.90\% of all epithelial and melanocytic skin tumors) and finally melanocytic tumors - 14 cases $(11.29 \%$ of all epithelial and melanocytic skin tumors). The age of dogs with epithelial and melanocytic cutaneous tumors ranged between 5 months to 15 years. The fact that the number of skin tumors diagnosed in 1999 was doubled in 2002 is of particular importance, which may be, the result of increasingly high interest of clinicians for biopsy-based diagnosis.

Key words: dog, epithelial, melanocytic, tumors

\section{INTRODUCTION}

A valid classification of cutaneous neoplasms is a basic prerequisite for adequate prognosis and application of the appropriate therapy, which was the basic reason for a new classification of skin tumors performed by WHO in 1999. Based on the most recent changes in nomenclature and classification, cutaneous dog tumors were categorized into three groups: a) epithelial and melanocytic skin tumors, b) mesenchymal tumors of the skin and soft tissues and c) hematopoietic tumors (Valli et al., 2002; Goldschmidt et al., 1999; Hendrick et al., 1999). Epithelial and melanocytic skin tumors appeared in approximately $38 \%$ of cases, while 
mesenchymal skin tumors appeared in $30 \%$ of cases (Chalita et al., 2001). The age of dogs with diagnosed skin tumors is commonly reported to range widely between 4 months and 16 years, although the average age approximately 9 years. (Kaldrymidou et al., 2002). Squamous cell carcinomas develop most frequently in Rottweilers, Giant Schnauzers and German shepherds at the age of approximately 8 years. Based on the findings reported by some authors, these tumors are associated with UV radiation (Guzman et al., 2003). Based on the majority of the studies, older male dogs are particularly endangered by malignant melanomas (Sulaimon et al., 2003). Sex disposition in certain tumors (Hepatoid gland adenoma) is attributed to hormonal activity and thus they are more frequently found in male animals in comparison to the females. (Kaldrymidou et al., 2002).

Adequate diagnosis and re-classification of skin tumors is also enabled by application of special staining methods and a wide range of immunohistochemical methods which, in addition to standard staining methods, make verification of Ki 67 and PCNA, i.e., cell proliferation antigens (Juntes et al., 2000; Abadie et al., 1999; Gerdes et al., 1992). Additionally, a frequently ambiguous picture of amelanotic melanoma and undifferentiated melanoma is elucidated by the application of S-100 and melan-A antibodies (Choi et al., 2003 Sulaimon et al., 2003; Ramos-Vara et al., 2002; Koenig et al., 2001), while histogenesis of certain epithelial neoplasms is enabled by application of intermediary filament markers (anti-cytokeratin, anti-vimentin, etc.) (Vos et al., 1993).

The reason for the high incidence of cutaneous neoplasms partially lies in the fact that the skin is permanently exposed to the influence of physical, chemical and other environmental factors, as well as that the neoplasms are easily recognized as early as in their initial stages (Guzman et al., 2003; Meleo, 1997; Bostock, 1986).

The main reason for our studies was an increasing number of these neoplasms found over the previous five-year period in our bioptic and section material. The need for retrospective analysis and re-classification of skin tumors is particularly emphasized by the fact that new protocols for treatment of these neoplasms have been introduced and adjusted over the recent years. Therefore, classification based on the latest WHO standards makes the prerequisite for an appropriate therapeutic and prognostic approach to the problem.

\section{MATERIAL AND METHODS}

Over the period $1999-2004$ a total of 211 skin tumor specimens were analyzed at the Department of Pathology, Faculty of veterinary medicine in Belgrade, out of which 5 were obtained upon post-mortem examinations while 206 were obtained upon biopsy. Out of the above stated number of skin tumors, 22 cases were diagnosed in 1999, 24 cases in 2000, 38 cases in 2001, 48 in 2002, 51 in 2003 while 28 cases were diagnosed over the first six months of 2004.

The studies included dogs of all breeds and both sexes (123 male dogs and 88 bitches), with their age ranging between 5 months and 15 years. 
Since the skin is an organ readily accessible to the examiner, the information on the localization of cutaneous neoplasms is obtained upon sampling.

The 211 tissue samples were fixed in $10 \%$ neutral buffered formalin and embedded in paraffin. Following the usual rehydration procedure, H\&E staining and in some cases immunostaining, peroxidase anti peroxidase -PAP method, were performed on 3 to $5 \mathrm{~mm}$ thick sections.

Immunohistochemistry: The peroxidase anti peroxidase PAP method was applied to the formaline fixed material using standard procedure. The expression of cytokeratin was detected, using Mouse-anti-human cytokeratin (Dako, M0717) and Rabbit-anti-cow S-100 (Dako Z0311) expression was investigated on melanocytic skin tumors using standard peroxidase-anti peroxidase immunostaining procedure on formalin fixed material.

\section{RESULTS}

Out of the total of 632 tumor specimens from dogs of different breeds subjected to pathohistological examinations over the period from 1999 until mid2004 (66 months), cutaneous tumors were diagnosed in 211 cases, i.e. in 123 (58.3\%) male animals and $88(41.7 \%)$ bitches, aged approximately 7 years, (ranging from 5 months to 15 years). Out of the 211 verified neoplastic lesions, 49 $(23.22 \%)$ were localized on skin of the head and neck, $53(25.11 \%)$ limb, 33 (15.64\%) trunk, $33(15.64 \%)$ on the anal and paraanal region, $6(2.84 \%)$ on the tail, while in $37(17.53 \%)$ cases the information on biopsy location was lacking.

Based on the final diagnosis out of 211 cutaneous neoplasms $113(53.55 \%)$ were malignant, while 98 (46.44\%) were benign tumors. In the studied material a total of 32 types of the cutaneous neoplasms were identified, out of which epithelial and melanocytic tumors were the most predominant (58.29\%), followed by hematopoietic tumors $(22.27 \%$ ) and mesenchymal skin and soft tissue tumors $(19.43 \%)$. Each of the three afore mentioned groups of cutaneous neoplasms was subjected to detailed histopathological analysis and the tumors were classified according to the latest WHO classification.

Out of the total of 66 tumor types contained in the WHO classification, 17 types were diagnosed in our specimens. The age of dogs with epithelial and melanocytic cutaneous tumors ranged between 5 months to 15 years, with the average age being 8 years. These neoplasms were most frequently verified in German Shepherd dogs, mixed breeds, Rottweilers, Cocker Spaniels and Boxers, predominantly on the head and neck skin in $35(28.26 \%)$ cases, anal and paraanal region skin in 31 (25\%), limb 26 (approximately $21 \%$ ), trunk $12(9.7 \%)$, while in 14 $(11.3 \%)$ cases the location was unknown. Out of the total number of tumors, 65 (52.42\%) were malignant, and 59 (47.58\%) were benign.

The most frequently diagnosed tumors in this group were the following: hepatoid adenoma, squamous cell carcinoma, basal cell carcinoma, malignant melanoma and sebaceous adenoma.

Hepatoid gland adenoma is a benign tumor of the modified sebaceous gland developing on the skin of the anal and paraanal region, as well as on the tail, hind limbs, laterally on the preputium, on the back and on other locations. Out of 
the total of 26 cases, 24 were observed in male dogs of mix breed, German shepherd dogs, Labradors, Samoyeds and Fox terriers aged approximately 9 years.

Table 1. Incidence of epithelial and melancytic tumors diagnosed at the Pathology department over the period from 1999 to 2004

\begin{tabular}{|l|c|c|}
\hline \multicolumn{1}{|c|}{ Tumor diagnosis } & Number & $\begin{array}{c}\% \text { out of all } \\
\text { cutaneous tumors }\end{array}$ \\
\hline \hline Epithelial and melanocytic tu & 123 & $58,29 \%$ \\
\hline \hline Hepatoid gland adenoma & 26 & $12,32 \%$ \\
\hline Squamous cell carcinoma & 20 & $9,48 \%$ \\
\hline Basal cell carcinoma & 16 & $7,58 \%$ \\
\hline Malignant melanoma & 12 & $5,69 \%$ \\
\hline Sebaceous adenoma & 9 & $4,26 \%$ \\
\hline Trichoepithelioma & 8 & $3,79 \%$ \\
\hline Hepatoid gland carcinoma & 8 & $3,79 \%$ \\
\hline Sebaceous carcinoma & 6 & $2,84 \%$ \\
\hline Papilloma & 4 & $1,90 \%$ \\
\hline Pilomatricoma & 3 & $1,42 \%$ \\
\hline Meibomian adenoma & 3 & $1,42 \%$ \\
\hline Melanocytoma & 2 & $0,95 \%$ \\
\hline Dermoid cyst & 2 & $0,95 \%$ \\
\hline Basosquamous carcinoma & 1 & $0,47 \%$ \\
\hline Malignant trichoepithelioma & 1 & $0,47 \%$ \\
\hline Apocrine adenoma & 1 & $0,47 \%$ \\
\hline Apocrine carcinoma & 1 & $0,47 \%$ \\
\hline
\end{tabular}

Squamous cell carcinoma is a malignant tumor which most frequently develops on the skin of the limb, trunk, head and neck, as well as on poorly pigmented skin areas. The largest number of these tumors was diagnosed in Rottweilers, Giant Schnauzers, German shepherds and standard poodles, with male to female ratio being 9 vs.11. The dogs were aged on average 7.7 years.

Basal cell carcinoma is a malignant tumor of the epidermal basal cells and it is mainly localized on the skin of the head and neck. It was diagnosed on the limb skin only in two cases while other affection sites have not been observed. These tumors are the most frequent in German shepherds, mix breeds, Standard Poodles and Cocker Spaniels, being more predominant in male dogs (12 cases) 
than in bitches (4 cases). The dogs affected with basal cell carcinomas were on averaged 5 years old.

Malignant melanoma is a malignant tumor of the pigmented tissue with prominent expression of S-100 protein. Skin biopsy specimens in which malignant melanoma was diagnosed were most frequently obtained from Dobermans, German Shepherds, Giant and Standard Schnauzers and Staffordshire terriers. Out of the total of 12 cases, 5 were found in male dogs while 7 originated from bitches. The average age of the dogs with this neoplasm was approximately 9 years.

Sebaceous adenomas are well demarcated intradermal masses composed of unevenly sized and shaped lobuli, whose cells are filled with intracytoplasmatic lipid vacuoles. They are most frequently located on the head and neck ( 3 cases), followed by limbs (2 cases), while 1 case each was evident on the trunk and anus. Based on our results, the following breeds are predisposed to this type of tumor: Cocker Spaniel, Epagneul Breton (French Brittany), Great Dane, Poodles and mix breeds. The number of cases was twice as high in male animals in comparison to the one found in bitches, the average age of these dogs was approximately 10 years.

\section{DISCUSSION}

The skin is the organ that is permanently exposed to the influence of physical, chemical and other environmental factors and it is readily accessible to clinical examinations. These are some of the reasons for more frequent diagnosis of cutaneous neoplasms (Meleo, 1997; Bostock, 1975). Out of the total number of tumors examined over the previous 66 months at the Department of pathology, skin tumors are found to be the second most frequent neoplasms with an incidence of $33.4 \%$, preceded only by mammary gland tumors (36\%), which is consistent with the findings of other authors (Benjamin et al., 1999; Moulton, 1990). Based on the most recent classification of canine cutaneous tumors developed by WHO in 1999 (Valli et al., 2002; Goldschmidt et al., 1999; Hendrick et al., 1999), the skin tumors found in our material were categorized in 3 groups. A valid classification is a basic prerequisite for appropriate prognosis and treatment of cutaneous neoplasms.

In our bioptic and section materials, epithelial and melanocytic skin tumors were the most frequent (58.75\%). Furthermore, four subgroups may be distinguished within the group: tumors with adnexal differentiation - 66 cases (53.23\% of all epithelial and melanocytic skin tumors), epidermal tumors - 25 cases $(20.16 \%$ of all epithelial and melanocytic skin tumors), tumors without squamous or adnexal differentiation - 16 cases $(12.90 \%$ of all epithelial and melanocytic skin tumors) and finally melanocytic tumors - 14 cases $(11.29 \%$ of all epithelial and melanocytic skin tumors). As for the incidence, the above tumors are followed by hematopoietic system tumors located in the skin $(22.27 \%)$ and mesenchymal skin and soft tissue tumors (18.95\%). The above frequencies differ from the results reported by other authors (Kaldrymidou et al., 2002; Chalita et al., 2001). 
According to the final diagnosis, out of the total of 211 cutaneous neoplasms, $113(53.55 \%)$ were malignant, while $98(46.44 \%)$ were benign, however, based on the findings reported by Kaldrymidou et al. (2002) malignant cutaneous tumors accounted for $46.6 \%$, while benign tumors accounted for 53.4\%. Bostock et al. (1975) reported the total number of malignant cutaneous neoplasms to be approximately $40 \%$. Sex disposition evidenced in certain tumors (Hepatoid gland adenoma) is attributed to hormonal activity being more predominant in male dogs - 58.3\%, with their age ranging from 5 months to 15 years, i.e., 7 years on average. Similar findings were also reported by Kaldrymidou et al. (2002) who evidenced sex disposition of $47.1 \%$ vs. $52.9 \%$ in favor of bitches, with their age ranging from 4 months to 16 years and average age being approximately 9 years.

Moreover, breed disposition, which is particularly prominent in certain types of tumors, is also an interesting parameter. Thus, mastocytomas develop most frequently in Boxers and squamous cell carcinomas develop most frequently in Rottweilers, Giant Schnauzers, German shepherds and standard Poodles at the age of approximately 8 years. Based on the findings reported by other authors, these tumors are associated with UV radiation (Guzman et al., 2003). Malignant melanomas are found in Dobermans, German Shepherds, Giant and Standard Schnauzers and Staffordshire terriers at the age of approximately 9 years, while based on the majority of the studies, older male dogs are particularly endangered by these neoplasms (Sulaimon et al., 2003). In the case of amelanotic melanoma, application of S-100 antibodies makes diagnosis easier (Choi et al., 2003; RamosVara et al., 2002; Koenig et al., 2001).

Based on the all afore mentioned, it may be concluded that canine cutaneous tumors are increasingly frequent and are severe a problem in the pathology of this animal species. Information on frequency and appearance of individual cutaneous tumors helps the clinicians to recognize them in time, perform appropriate sampling and after obtaining the results of histopathological and immunohistochemical analyses, give a correct prognosis and determine a therapy as effective as possible. The incentive to carry out this study was given by the increasingly frequent finding of these neoplasms over the previous five-year period in our bioptic and section materials. The need for retrospective analysis and reclassification of cutaneous tumors is particularly emphasized by the fact that new protocols for the treatment of these neoplasms are being introduced and adjusted over the last years. Therefore, the classification based on the latest WHO standards makes the prerequisite for an appropriate therapeutic and prognostic approach to the problem.

ACKNOWLEDGMENTS:

This paper was supported by grant 1659 from the Ministry of Science and Technology of the Republic of Serbia. 
Address for correspondence:

Sanja Aleksić-Kovacević

Department of Pathology,

Faculty of Veterinary Medicine, University of Belgrade

Bulevar JA 18, 11000 Beograd,

Serbia\&Montenegro

E-mail: skovacevicŽvet.bg.ac.yu

\section{REFERENCES}

1. Abadie JJ, Amardeilh MA, De/verdier ME, 1999, Immunohistochemical detection of proliferating cell nuclear antigen and Ki-67 in mast cell tumors from dogs, J Am Vet Med Assoc, 215, 11, 1629-34

2. Benjamin SA, Lee AC, Saunders WJ, 1999, Classification and behavior of canine mammary epithelial neoplasms based on life-span observations in beagles, Vet Pathol, 36, 423-36.

3. Bostock DE, 1986, Neoplasms of the skin and subcutaneous tissues in dogs and cats, Br Vet J, 142, 1-19

4. Bostock DE, Owen $L N, 1975$, The skin and adnexa, In: Neoplasia in the cat, dog end horse, Wolfe Medical Publications Ltd., Smeets-Weert, Holand, 15-47.

5. Chalita MC, Matera JM, Alves MT, Longatto Filho A, 2001, Nonaspiration fine needle cytology and its histologic correlation in canine skin and soft tissue tumors, Anal Quant Cytol Histol, 23, 395-9.

6. Choi $C$ and Kusewitt $D F, 2003$, Comparison of tyrosinase-related protein-2, $\mathrm{S} 100$ and melan $A$ immunoreactivity in canine amelanotic melanomas, Vet Pathol, 40, 713-8

7. Gerdes J, Becker MHG et al., 1992, Immunohistological detection of tumor growth fraction (Ki-67 antigen) in formalin-fixed and routinely processed tissues, $J$ Pathol, 168, 85-6

8. Goldschmidt MH, Dunstan RW, Stannard AA, Tscharner C et al., 1998, Histological classification of epithelial and melanocytic tumors of the skin of domestic animals, second edition, WHO, Armed Forces Institute of Pathology and American Registry of Pathology, Washington D.C.

9. Guzman E, Langowski JL, Owen-Schaub L, 2003, Mad dogs, Englishmen and apoptosis: The role of cell death in UV-induced skin cancer, Apoptosis, 4, 315-25.

10. Hendrick MJ, Mahaffey EA, Moore FM, Vos JH, Walder EJ, 1998, Histological classification of mesenchymal tumors of skin and soft tissues of domestic animals, second edition, WHO, Armed Forces Institute of Pathology and American Registry of Pathology, Washington D.C.

11. Juntes $P$ and Pogacnik M, 2000, Morphometric analysis of AgNORs in tubular and papillary parts of canine mammary gland tumors, Analytical and Quantitative cytology and histology, 22, 185-92

12. Kaldrymidou H, Leontides L, Koutinas AF, Saridomichelakis MN and Karayannopoulou M, 2002, Prevalence, distribution and factors associated with the presence and the potential for malignancy of cutaneous neoplasms in 174 dogs admitted to a clinic in Northern Greece, $J$ Vet Med, 49, 87-91.

13. Koenig A et al., 2001, Expression of S100a, vimentin, NSE and melan A/MART-1 in seven canine melanoma cell lines and twenty-nine retrospective cases of canine melanoma, Vet Pathol, 38, 427-35

14. Meleo KA, 1997, Tumors of the skin and associated structures, Vet Clin North Am Small Anim Pract, 27, 73-94.

15. Moulton JE, 1990, Tumors of the Skin and Soft Tissues, In: Tumors in domestic animals, third edition, University of California Press, Ltd. London, 23-75.

16. Ramos-Vara JA et al., 2002, Melan A and S-100 protein immunohistochemistry in feline melanomas: 48 cases, Vet Pathol, 39, 127-32

17. Sulaimon SS, Kitchell BE, 2003 , The basis biology of malignant melanoma: molecular mechanisms of disease progression and comparative aspects, $J$ Vet Intern Med, 17, 760-72.

18. Valli VE, Jacobs RM, Parodi AL, Vernau W, Moore PF, 2002, Histological classification of hematopoietic tumors of domestic animals, second edition, WHO, Armed Forces Institute of Pathology and American Registry of Pathology, Washington D.C. 
19. Vos JH van den Ingh TSGAM et al., 1993, Immunohistochemistry with keratin, vimentin, desmin and a-smooth muscle actin monoclonal antibodies in canine mammary gland: malignant mammary tumors, The Veterinary Quaterly, 15, 3, 96-102.

\title{
RETROSPEKTIVNA ANALIZA EPITELNIH I MELANOCITNIH TUMORA KOŽE PASA
}

\author{
ALEKSIĆ-KOVAČEVIĆ SANJA, KUKOLJ V, MARINKOVIĆ D i KNEŽEVIĆ MILIJANA
}

\section{SADRŽAJ}

Od ukupnog broja tumora pasa dijagnostikovanih iz biopsijskog i sekcionog materijala, na Katedri za patologiju u poslednjih pet godina, najčešći su bili tumori kože i tumori mlečne žlezde - u 33.4\% odnosno 36 \% slučajeva. Tumori kože dijagnostikovani su kod 211 pasa - 123 mužjaka $(58,3 \%)$ i 88 ženki $(41,7 \%)$, različitih rasa i prosečne starosti oko 7 godina.Od ukupnog broja tumora kože dijagnostikovana su 32 tipa kutanih neoplazmi, sa dominantno prisutnim epitelnim i melanocitnim tumorima, zatim slede intradermalne hematopoezne neoplazme i mezenhimski tumori kože i mekih tkiva. U našem biopsijskom i sekcionom matrijalu u okviru najbrojnijih, epitelnih i melanocitnih tumora dijagnostikovanih u 123 $(53,23 \%)$ slučaja, nalaze se četiri grupe: tumori sa adneksalnom diferencijacijom u 66 slučajeva (53,23\%), epidermalni tumori - 25 slučajeva $(20,16 \%)$, tumori sa skvamoznom i adneksalnom diferencijacijom 16 slučajeva $(12,90 \%)$ i konačno melanocitni tumori u 14 slučajeva $(11,29 \%)$ svih epitelnih i melanocitnih tumora. Starost pasa sa epitelnim i melancitnim tumorima je u intervalu od 5 meseci do 15 godina. Činjenica da je broj tumora kože dijagnostikovanih u 1999. godini udvostručen u u 2002., od posebnog je značaja, a između ostalog može ukazivati i na sve veće interesovanje kliničara za biopsijske dijagnoze. 